
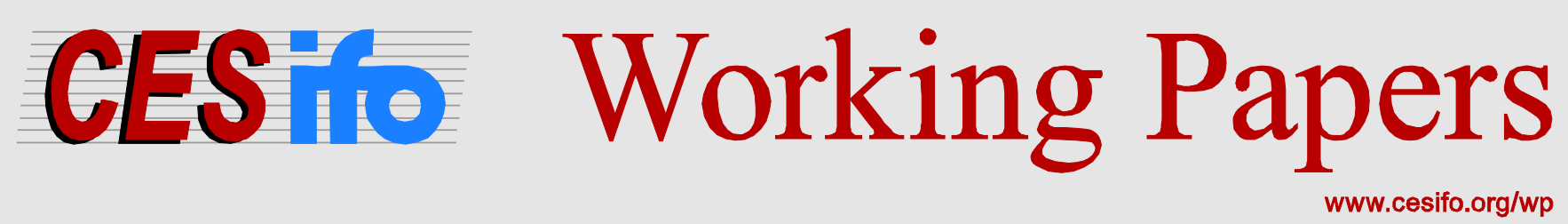

\title{
Credit Shocks and Macroeconomic Fluctuations in Emerging Markets
}

\author{
Romain Houssa \\ Jolan Mohimont \\ Chris Otrok
}

\begin{abstract}
CESIFO WORKING PAPER NO. 4281
Category 7: Monetary Policy and International Finance

JUNE 2013
\end{abstract}

Presented at CESifo Area Conference on Macro, Money \& International Finance, February 2013

An electronic version of the paper may be downloaded

- from the SSRN website:

WwW.SSRN.com

- from the RePEc website:

- from the CESifo website:

www.RePEc.org

www.CESifo-group.org/wp

\section{CESifo}




\title{
Credit Shocks and Macroeconomic Fluctuations in Emerging Markets
}

\begin{abstract}
In this paper, we examine the role of global and domestic credit supply shocks in macroeconomic fluctuations for Emerging Markets. For this purpose, we impose a set of zero and sign restrictions within a medium-scale Bayesian Vector Auto-Regressive model. Quarterly data from South Africa and G-7 countries in 1985-2010 show that credit supply shocks impact significantly on macroeconomic aggregates in these economies. However, credit supply shocks have played, on average, a less important role than credit demand shocks. Moreover, shocks originating from G7-countries are the main drivers of real activity in South Africa, although they played a marginal role in the 1996-1999 South African recession.

JEL-Code: C510, C330, C150, C530, E300, E430, E520, N170.
\end{abstract}

Keywords: credit shocks, developing countries, macroeconomic stabilization policies, sign restrictions, Bayesian VAR.

\author{
Romain Houssa \\ CRED \& CeReFiM \\ University of Namur \\ Rempart de la Vierge 8 \\ Belgium - 5000 Namur \\ romain.houssa@fundp.ac.be
}

\author{
Jolan Mohimont \\ CRED \& CeReFiM \\ University of Namur \\ Namur / Belgium \\ jmohimon@unamur.be
}

\author{
Chris Otrok \\ Department of Economics \\ University of Missouri \\ USA - Columbia, MO, 65211 \\ otrokc@missouri.edu
}

May 24, 2013

We are grateful for helpful comments from participants at workshops, seminars, and conferences: the 2013 CESifo-Area Conference on Macro, Money and International Finance in Munich, the 2013 ESL Doctoral Workshop in Namur, the 2013 CSAE conference in Oxford, and seminars at IREEP and ENIAM in Cotonou. The usual disclaimer applies. 


\section{Introduction}

The great recession that followed the recent global financial crisis has spurred a renewed interest in the assessment of the real effects of credit shocks. One problem faced with the identification of this type of shocks in earlier studies is the difficulty to disentangle credit supply shocks from their demand counterparts (e.g. Bernanke and Lown (1991) and Trautwein (2000)). Recent quantitative methods offer some solutions to this identification problem by allowing to impose theoretical justifiable sign restrictions on impulse response functions (e.g. Canova and Nicolo (2002), Faust (1998), and Uhlig (2005)). For instance, Meeks (2012) applies this method to the USA and finds that credit supply shocks impact significantly on real activity but their overall role in driving macroeconomic fluctuations is limited. On the contrary, Gilchrist et al. (2009) use a recursive identification scheme and present evidence suggesting that these shocks account for a larger share of output fluctuations in the USA.

Helbling et al. (2011) provide a global analysis on credit supply shocks. Using the sign restriction identification scheme they find that global credit supply shocks account for a similar share as global productivity shocks for real activity in G-7 countries. Moreover, they document that credit supply shocks have been more important in the 2007 - 2009 global recession as compared to the 1990 - 1991 episode. Related studies on Europe employing sign restrictions report mixed results (e.g. Abildgren (2012), Busch et al. (2010), Halvorsen and Jacobsen (2009) and Torsten and Zwick (2012) Hristov et al. (2012)). On the one hand, Hristov et al. (2012) and Halvorsen and Jacobsen (2009) find that loan supply shocks play a minor role for output fluctuations in the Euro Area and the UK, respectively. Even Abildgren (2012) argue that lending supply shocks have no effects on output in Denmark in 1922 - 1949 and 1981 - 2011. On the other hand, Halvorsen and Jacobsen (2009) and Busch et al. (2010) find that loan supply shocks account for a larger share of output fluctuation in Norway and Germany, respectively. In a related study Gambetti and Musso (2012) employ the identification scheme based on sign restrictions within time varying BVAR models. They find that loan supply shocks account for about $20 \%$ of the variance of real activity in UK, USA and the Euro Area. Moreover, they argue that these shocks have increased in importance in recent years.

While this literature is growing, it almost entirely focuses on advanced countries. To the best of our knowledge only Tamasi and Vilagi (2011) explicitly identify credit supply shocks 
for EMEs. They employ a BVAR model with sign restrictions and report that credit supply shocks account for a larger share of output fluctuations in Hungary. Other related studies have mainly used regression techniques to document a positive co-movement between credit and real activity (e.g. Akinboade and Makina (2010)). However, in such a framework is it difficult to distinguish correlation from causality. Moreover, such techniques do not systematically analyze non-expected shocks. For research studying international transmission of credit shocks to EMEs; see Schnabl (ming) and Cetorelli and Goldberg (2010)).

In this paper, we examine the role of global and domestic credit supply shocks in macroeconomic fluctuations in Emerging Markets (EMEs). For this purpose, we use a mediumscale Bayesian Vector Auto-Regressive (BVAR) model and employ a set of zero and sign restrictions. On the one hand, zero restrictions allow to disentangle domestic from global shocks. In particular, we assume that G7 countries do not respond to shocks originating from EMEs. This type of identification restriction has been used in other contexts. However, to our knowledge, this is the first time it is used to analyze the economic impacts of global versus domestic credit supply shocks. Knowing the origin of credit supply shocks will help design appropriate macroprudential policies.

On the other hand, sign restrictions are used to distinguish credit supply shocks from credit demand shocks. Especially, credit demand shocks capture endogenous responses of credit market indicators to fundamental shocks whereas credit supply shocks are the variations in these indicators that are unrelated to fundamentals (see e.g. Helbling et al. (2011) and Meeks (2012)). For instance, following adverse credit supply shocks we require that the volume of credit and default rates do not increase. In the case of adverse credit demand shocks we also require a drop in the volume of credit but we impose that default rates cannot decrease. We consider two types of fundamental shocks that drive credit demand shocks: productivity shocks and aggregate demand shocks. Evaluating credit supply shocks against these two fundamental shocks may improve identification because the response of inflation to credit supply shocks is not signed a priory. One the one hand, negative credit supply shocks may lead to more inflation via the increase of the cost of credit or/and real wages (see, e.g., Gerali et al., 2010 and Atta-Mensah and Dib, 2008). On the other hand, credit supply shocks may decrease inflation because of the contraction of aggregate demand induced by the decrease of credit volume (see, e.g., Curdia and Woodford, 2010).

In the implementation we proxy global shocks by G7-shocks. For EMEs data availability forces us to choose South Africa (SA). In total we identify six orthogonal shocks: G7-credit shocks, G7-productivity shocks, G7-demand, SA-credit shocks, SA-productivity shocks, and SA-demand shocks. We study the impacts of various shocks through the analysis of impulse 
response functions and variance decomposition. In addition, counterfactual analysis is used to examine the role of each shock in three South African recessions: 1990 : $1-1992$ : 2; $1996: 3-1999: 1$ and $2007: 3$ - $2010: 3$. Moreover, we study three transmission channels of G7-shocks to South Africa: credit, trade volume, and commodity price channels (see for instance, Broda (2004) Deaton and Miller (1996) Hoffmaister and Roldós (1997); Hoffmaister et al. (1998), Houssa (2008b,a), Houssa et al. (2010) and Kose (2002), Kose and Riezman (2001), Mendoza (1995), Chia and Alba (2006)).

In addition to contributing to the current debate, there are at least three reasons for studying credit shocks for EMEs. First, financial intermediaries are the main financing sources in these economies. As such, credit supply shocks might play different roles in business cycles. Second, EMEs have increasingly become major players at the global level by intensifying their trade and financial linkages with advanced countries but also with Low Income Countries (LICs). In this context, understanding shocks originating from these economies will provide insights on the evolution of the global business cycles. Third, there is a large literature on international business cycles but their transmission channels are not well understood. Our study contributes to this debate by examining different channels of global shocks to South Africa at specific times.

Quarterly data from South Africa and G7 countries in 1985 : 1 - 2010 : 3 indicate that domestic and global credit supply shocks have played a statistically significant role on macroeconomic aggregates in these economies. However, fundamental shocks remain the main drivers of macroeconomic fluctuations in G7 countries but also in South Africa. Shocks originating from G7-countries account for the larger share of the variation in real activity in South Africa, although they played a marginal role in the 1996 - 1999 South African recession. Moreover, the three type of G7-shocks have contributed significantly to the $2007: 4-2010: 3$ recession whereas productivity shocks were the main drivers of real activity in the $1990: 1-1992: 2$ episode.

The remainder of this paper is organized as follows. Section 2 introduces the BVAR model and discusses the structural identification strategy. Section 3 presents empirical results. Section 4 concludes. 


\section{Methodology}

\subsection{Bayesian Vector Auto-Regressive (BVAR) Model}

Consider the following Vector Auto-Regressive $(V A R)$ model,

$$
Y_{t}=A_{0}+A_{1} Y_{t-1}+\ldots+A_{P} Y_{t-P}+\mu_{t}
$$

where $Y_{t}$ is a $16 \times 1$ vector of real, nominal and financial indicators on G7-countries and South Africa, the $A_{i}$ are $16 \times 16$ auto-regressive coefficients, $A_{0}$ contains the constant terms, and $\mu_{t}$ is a $16 \times 1$ vector of Gaussian white noise with covariance matrix $\Psi=E\left(\mu_{t} \mu_{t}^{\prime}\right)$.

We estimate Eq. (1) using Bayesian methods with 3 lags and a combination of two types of priors: i) a Normal-inverted Wishart prior; and ii) a Minnesota type prior that assigns low weights on off-diagonal AR coefficients and specifically zeros weights on coefficients related to South African indicators in the block defined by commodity prices and G7-factors. ${ }^{1}$ We estimate four G7-factors by extracting the first principal component from the series of G7 countries: G7-real GDP; G7-inflation; G7-real credit; and G7-short-term interest rates. In addition, we use two US series in the G7-block: US-credit spread and US-default rates. The remaining 10 series contained in $Y_{t}$ relate to the South African economy.

We derive quarterly data from South Africa and G7-countries in 1985 : $1-2010: 3$. Where appropriate we transform the series in year to year growth rates. Table 1 reports detailed information on the dataset and the transformation applied to each series. For the South African economy we measure credit spread by the difference between the yield on Eskom and the US baa bond. As a proxy for the default rate we make use of data on the number of insolvency on loans. For G7 we use the US corporate credit spreads: baa-aaa. For a measure default rate for G7 we also use a proxy for the US economy. In particular, we use the distance to default measure proposed by Gilchrist et al. (2009). We take the inverse of this indicator and transform it to year to year growth rate.

\subsection{Structural Identification}

We employ a set of zero and sign restrictions. These restrictions are implemented with the penalty function approach proposed by Mountford and Uhlig (2009) and Uhlig (2005). We explicitly modify the objective function in order to impose both zero and sign restrictions. The results reported in the paper are based on the following sequential ordering: G7-credit shocks,

\footnotetext{
${ }^{1}$ The results reported in the paper are based on 250 draws. Using a larger number of draws leaves qualitatively the results unchanged.
} 
G7-productivity shocks, G7-demand shocks, SA-credit shocks, SA-productivity shocks, and SA-demand shocks. However, using different ordering does not change the main results of the paper. Table 2 reports the identification restrictions for the six shocks. In all cases, the restrictions assume negative shocks and are imposed over the first four quarters.

Zero restrictions allow to disentangle South African shocks from global shocks. In particular, we assume that G7 countries do not respond to shocks originating from South Africa. On the other hand, sign restrictions help to distinguish credit supply shocks from credit demand shocks. Especially, credit demand shocks capture endogenous responses of credit market indicators to fundamental shocks whereas credit supply shocks are the variations in these indicators that are unrelated to fundamentals.

The identification of credit supply shocks is based on Helbling et al. (2011) and Meeks (2012). We assume that an adverse credit supply shock is characterized by an increase in the credit spread and a decrease in real credit. In addition, we require that default rates on corporate bonds do not increase. This additional restriction helps to isolate the endogenous response of credit to fundamental macroeconomic shocks (see Meeks (2012)). Note that we leave unrestricted the IRFs of Real GDP, inflation, the monetary policy rate and other series.

For adverse productivity and aggregate demand shocks, we also impose that the volume of credit decreases. However, we also require for these shocks that default rates do not decrease. Finally, we use additional restrictions to discriminate between productivity shocks and aggregate demand shocks. Especially, we assume that productivity shocks generate a negative comovement between output and inflation whereas aggregate demand shocks imply a positive comovement between the two indicators.

\section{Empirical Results}

\subsection{Estimated Shocks}

Figures 1 and 2 report the median together with the 16th and 84th percentiles of the estimated shocks. ${ }^{2}$

The narrowness of the majority of credible intervals suggests that the shocks are precisely estimated.

The estimated shocks capture the main events that occurred at the global level and in South Africa in the last decades. In particular, the estimated G7-shocks mimic the fluctuations of the global business cycles presented in the literature (e.g. Gregory et al.

\footnotetext{
${ }^{2}$ The data have been normalized such that positive numbers represent favorable shocks.
} 


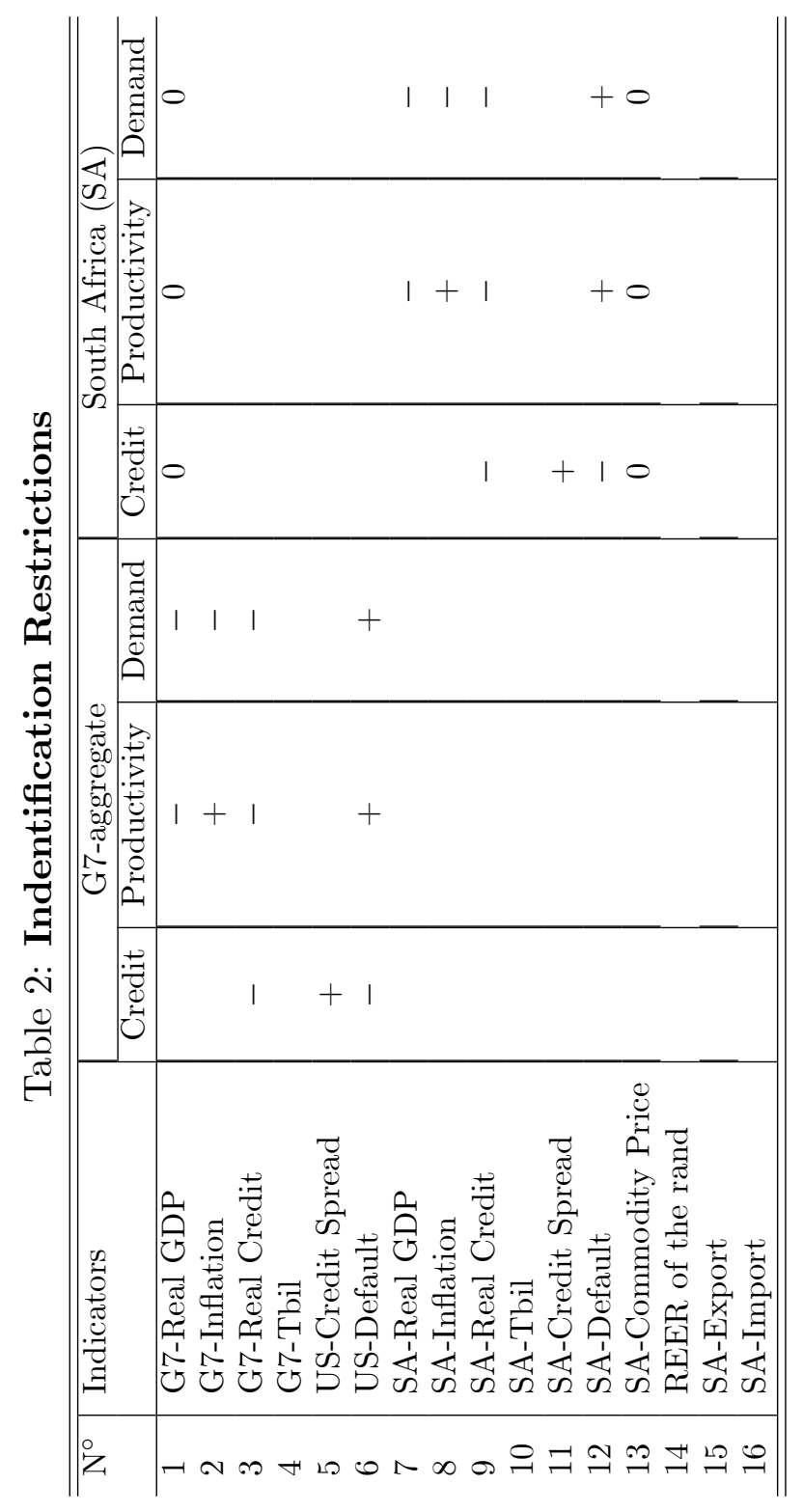


Figure 1: Estimated G7-shocks
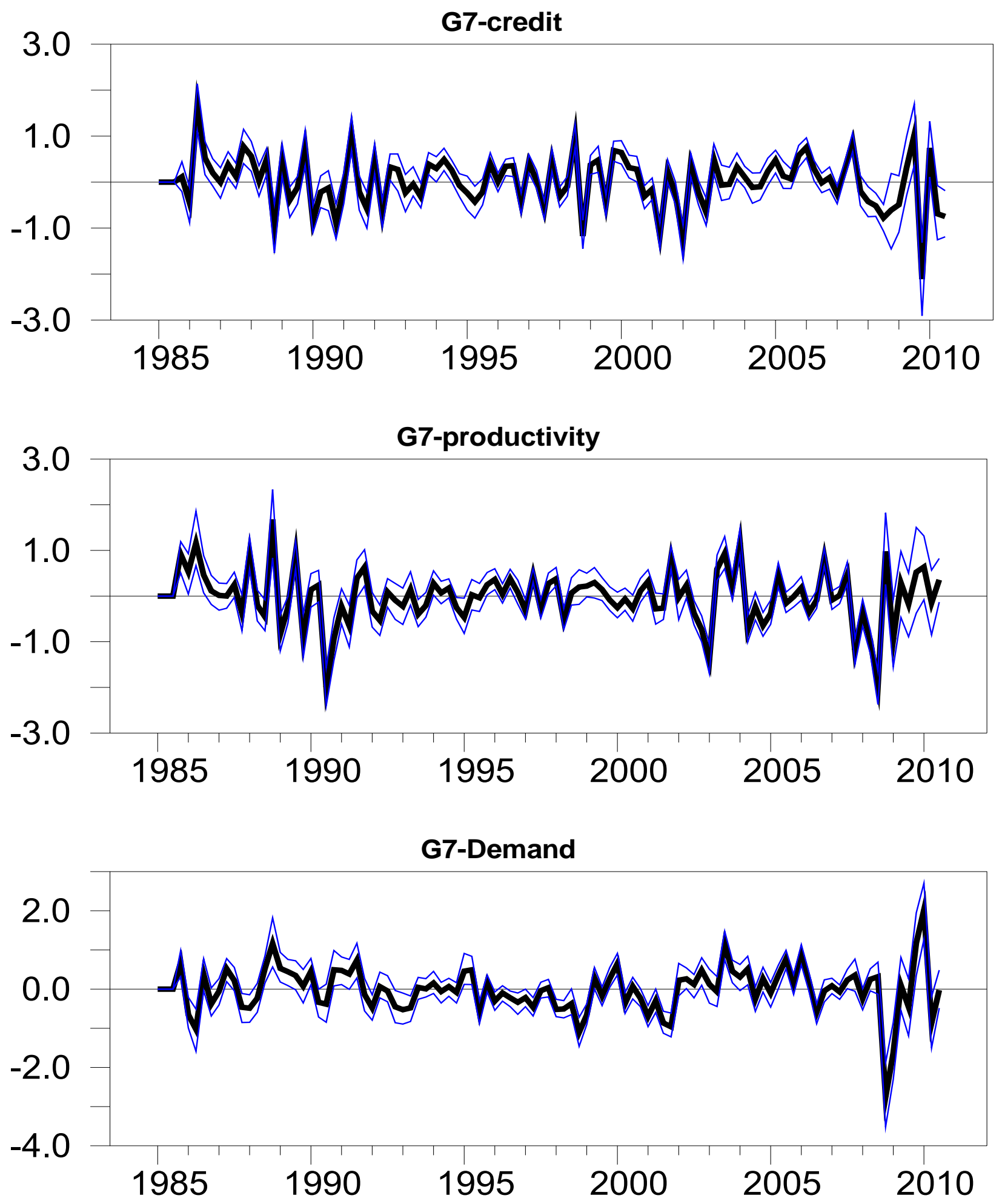
Figure 2: Estimated South African Shocks
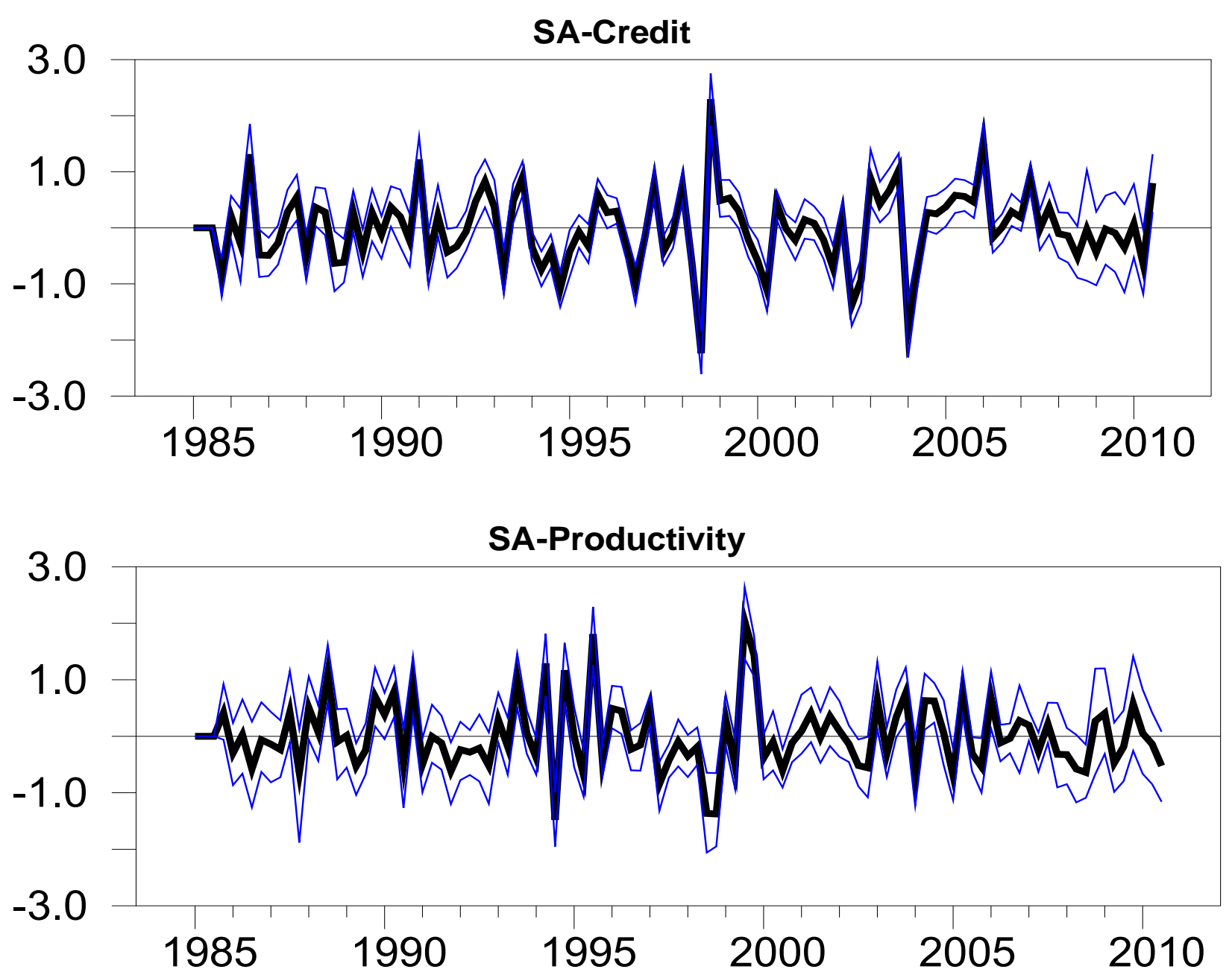

SA-Demand

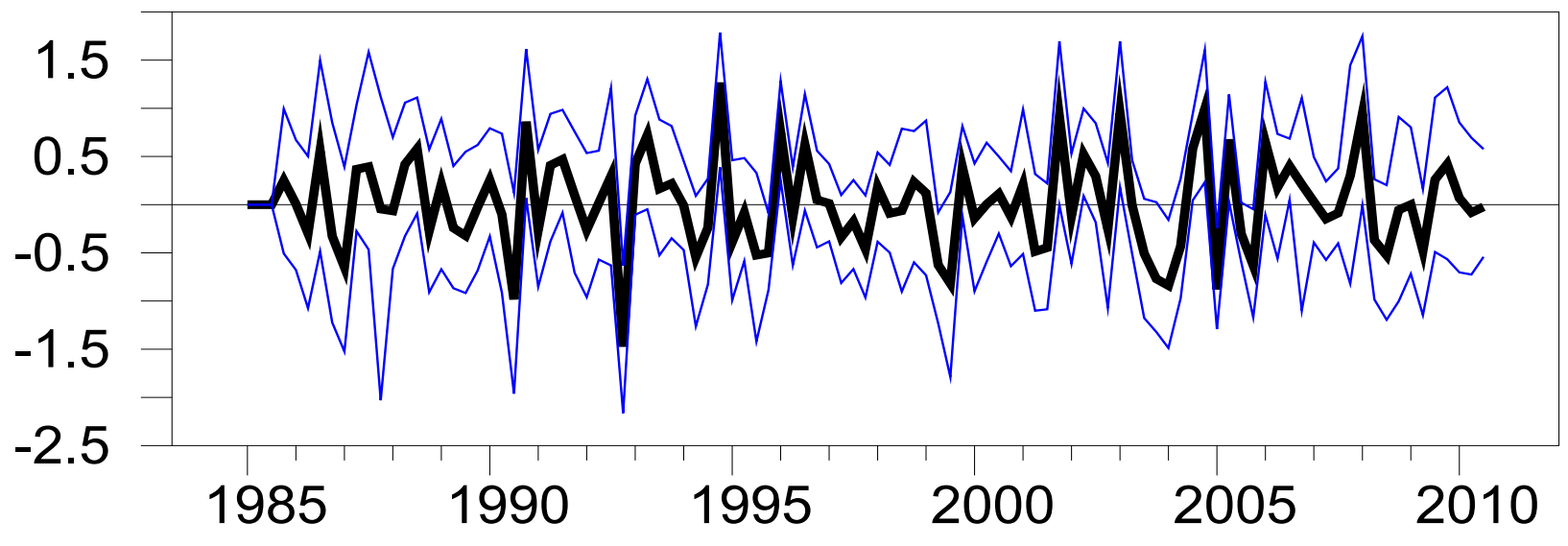


(1997), Kose et al. (2003) and Kose et al. (2003)). For instance, our estimated G7-shocks show large negative deviations in 2007 - 2009, corresponding to the recent financial crisis and the associated great recession (Figure 1). The data also show that positive demand developments play an important role in the first stage of the recovery from the great recession. The G7-credit and productivity shocks capture the global recession that occurred in the early 1990s following the USA credit crunch in 1991, the crisis in the European Exchange Rate Mechanism, and the oil shock related to the Gulf war in Iraq. In the same way these two shocks are in line with the global recession of the early 2000s, coinciding with the bursting of the equity market and information technology bubbles.

The estimated South African shocks capture specific events (Figure 2). For instance, contrary to the G7 shocks, the South African shocks do not display any significant negative deviations during the great recession period. Only the South African productivity shocks indicate a small negative deviation in early-2008, corresponding to the electricity power shortage that happened in the country.

The negative movements in the domestic shocks before mid-1995 coincided with a number of events including a severe drought, problems in the mining sector but also social and political developments. The latter caused a deterioration in investors' confidence and encouraged foreign banks to withdraw funds from the country (see, e.g., South African Reserve Bank (1995) and Van der Walt and Pretorius (1995)).

The domestic credit supply and productivity shocks exhibit significant negative deviations in the second half of the 1990s and earlier $2000 \mathrm{~s}$ coincided with the Asian and Russian financial crisis in 1997 - 1998 and financial crises in Brazil and Argentina in early 2000, adverse gold price shocks in 1995 - 1997, the banking crisis in 2002, which resulted in the collapse of a number of banks in South Africa (see, e.g., South African Reserve Bank (2005), Venter and Pretorius (2001) and Venter (2009)).

\subsection{Dynamic Responses Analysis}

Figures 3 to 5 display the median together with the 16 th and 84 th percentiles of the dynamic responses to the six shocks. In general the unconstrained IRFs are in line with intuition.

For instance, the IRFs to the domestic and global credit supply shocks impact significantly on real activity. Especially, the global credit shocks cause recessions in both the G7 countries and in South Africa. In the same way the domestic credit supply shocks contracts significantly real activity in South Africa.

The global credit shocks raise significantly G7-inflation on impact but reduces it later 
Figure 3: Dynamic responses to credit shocks

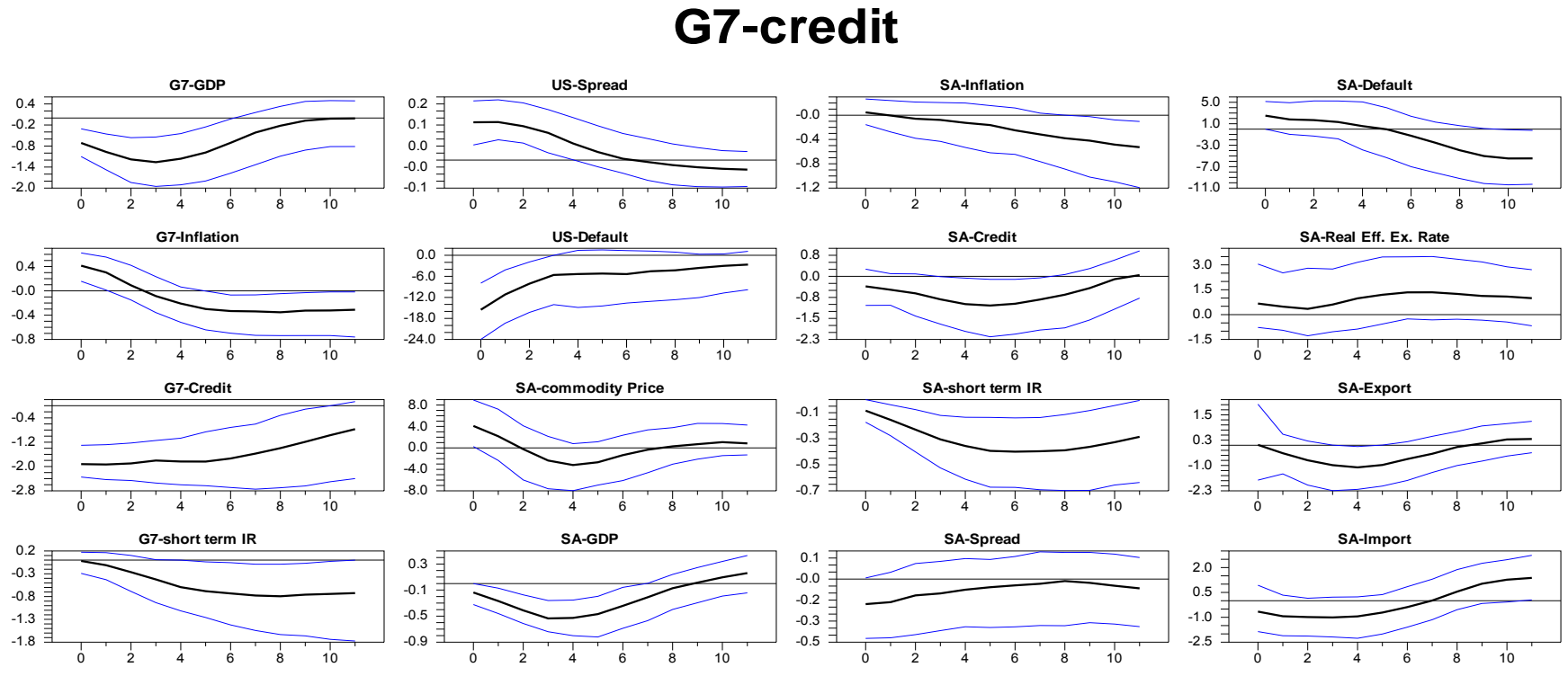

\section{SA-Credit}
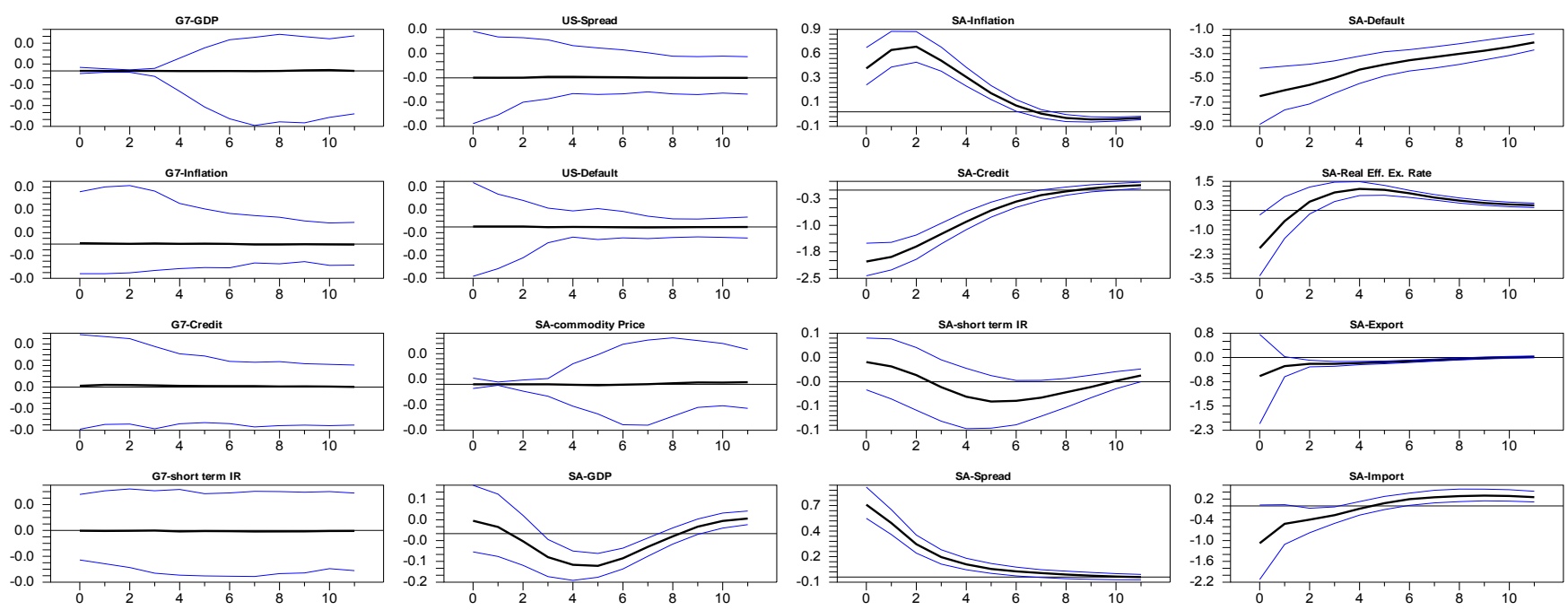
Figure 4: Dynamic responses to productivity shocks

\section{G7-productivity}
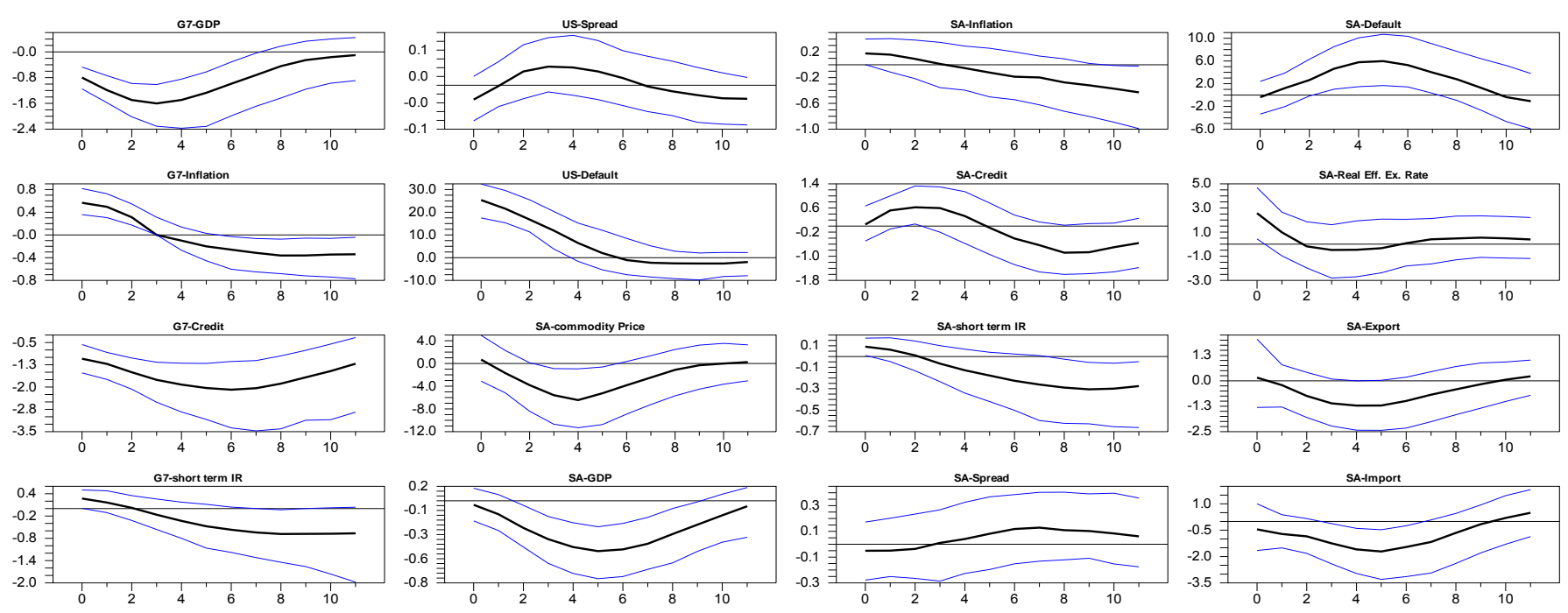

\section{SA-Productivity}
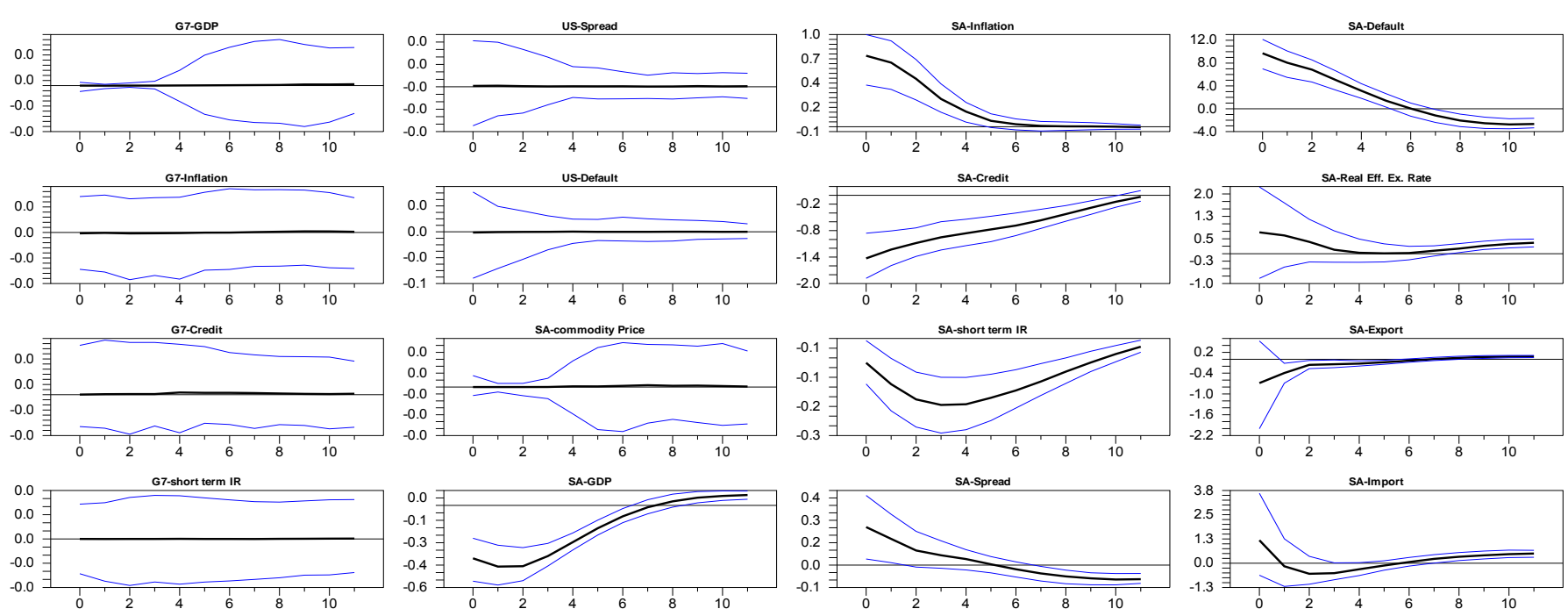
Figure 5: Dynamic responses to demand shocks

\section{G7-Demand}
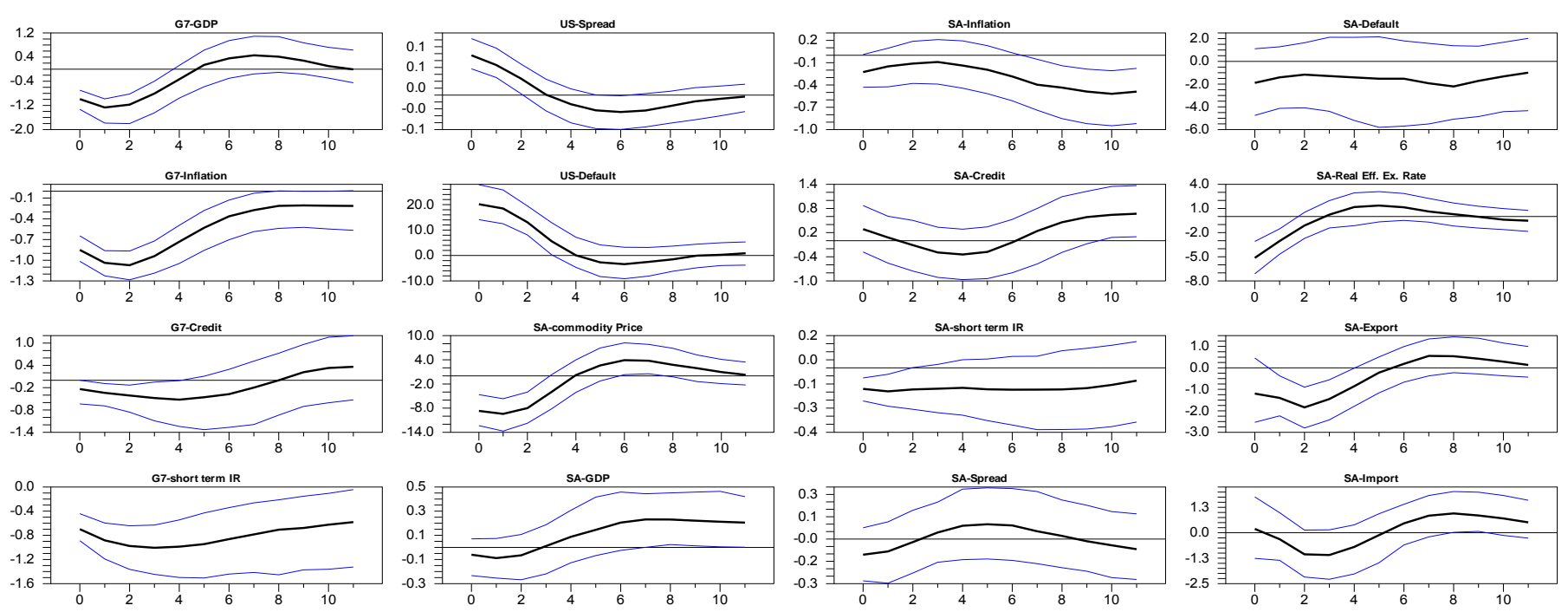

\section{SA-Demand}
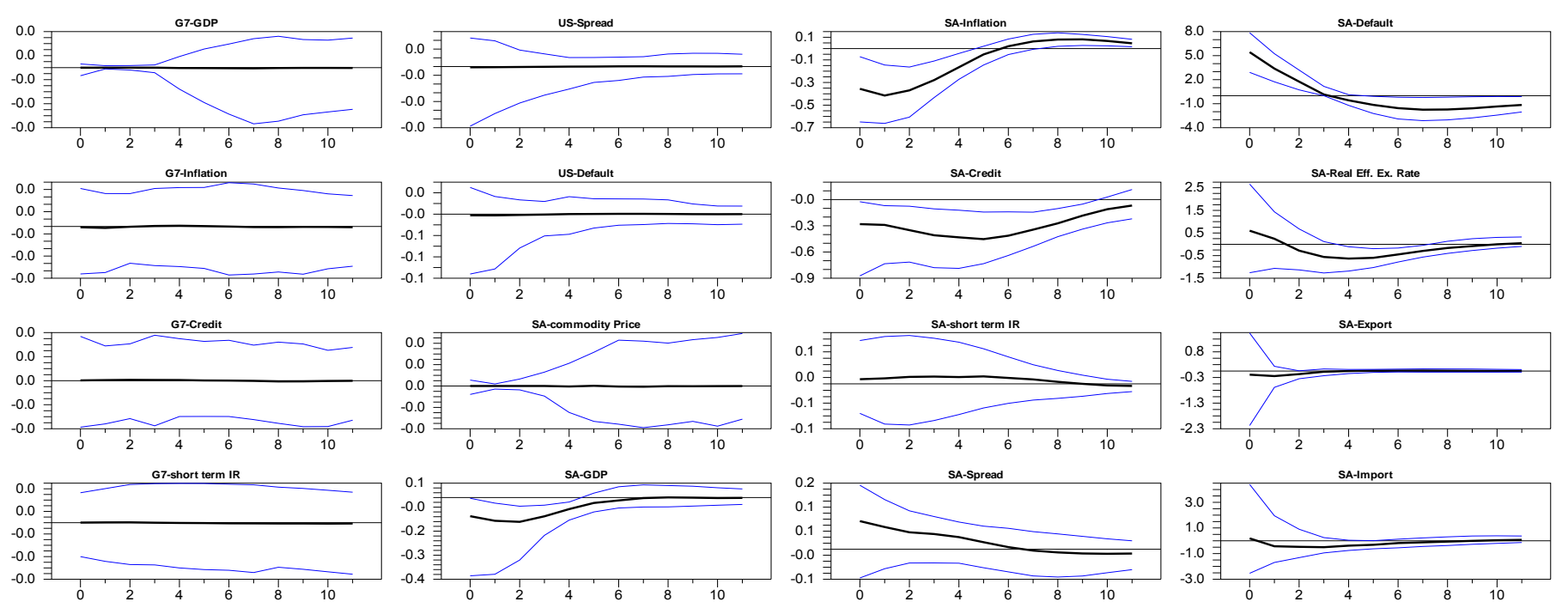
around six quarters. The domestic credit supply shocks generate a similar inflationary pressures on impact in South Africa but these effects persist over six quarters. These inflation pressures of credit supply shocks are in line with the models presented in Atta-Mensah and Dib (2008) and Gerali et al. (2010) whereas the negative inflation effect of the second phase are supported by the models presented in Curdia and Woodford (2010). Despite the initial inflationary effects our results show that the monetary authorities ease their policy certainty because credit supply shocks generate a deeper recession.

Concentrating on the impacts of external shocks on South Africa in general the data reported in Figures 3 to 5 show that adverse global shocks have caused recessions in South Africa although the results are not statistically significant for aggregate demand shocks. In line with these findings global productivity and credit supply shocks increase the probability of firms to default in South Africa. As in the case of global credit shocks the South African Reserve Bank (SARB) also accommodates the global productivity and aggregate demand shocks. Moreover, the global shocks transmit to South Africa through three channels: trade linkages, credit channels and primary commodity price channels.

Turning to the domestic shocks the data show that credit spreads increase in the events of averse productivity and aggregate demand shocks. Moreover, export and imports contracts. As such, the SARB accommodates these shocks as well.

\subsection{Variance Decomposition Analysis}

Figures 6 to 8 report the median of the percentage share of the variance attributed to each of the six shocks.

The results can be summarized in the following three points. First, the global shocks explained the main variations of macroeconomic aggregates in South Africa. Concentrating on the 3-year horizon variance decomposition (VD) of real activity in South Africa, the global demand shocks play the dominant role $^{3}$ and the two remaining global shocks explain about the same share. A similar result holds true for the VD of the G7-output. The finding that the global credit supply shocks account for a similar share as global productivity shocks for real activity in G-7 countries is in line with Helbling et al. (2011). However, our estimates suggest this share to be about $15 \%$ whereas Helbling et al. (2011) find $12 \%$.

Second, at the 3-year horizon the global shocks also account for the main variation of the South African inflation. In the short-run, however, domestic shocks play the dominant role. Especially, the domestic productivity shocks explain the largest share of the variance of

\footnotetext{
${ }^{3}$ In the short-run, however, the domestic productivity shocks is more important.
} 
Figure 6: Variance explained by credit shocks

G7-credit

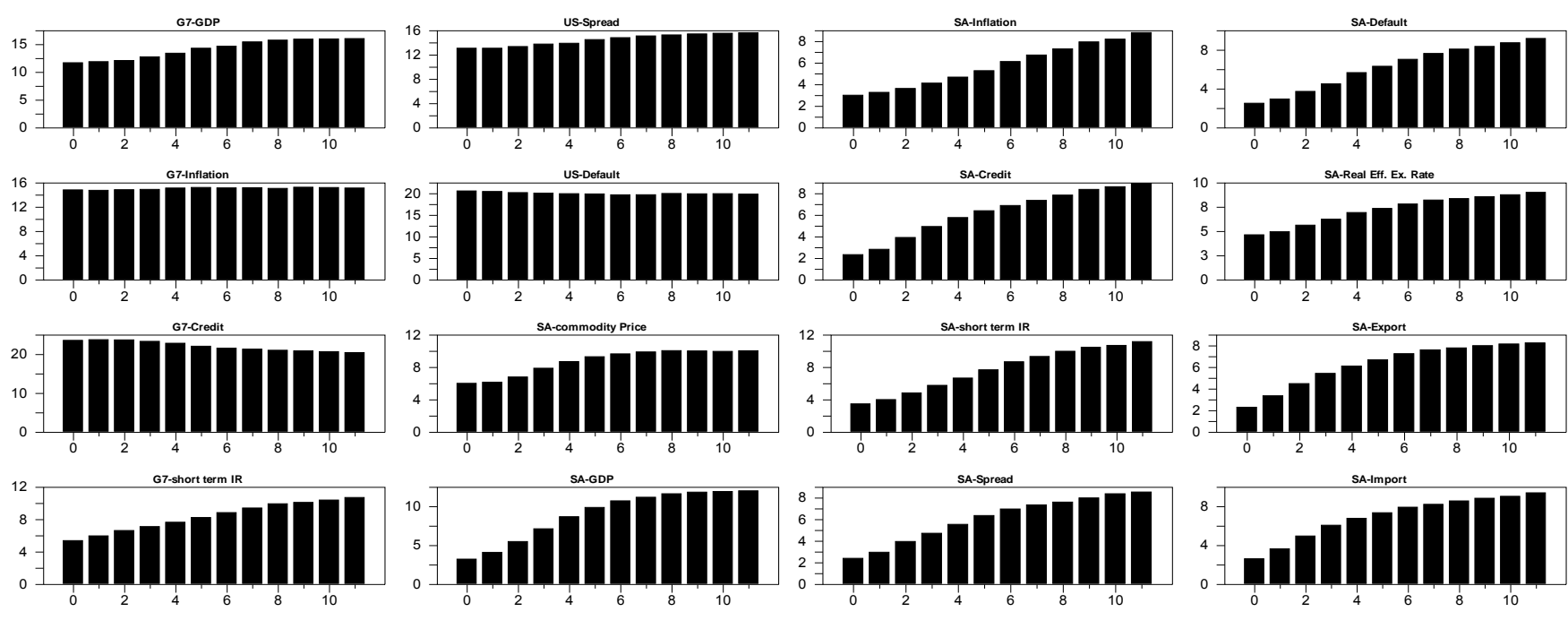

SA-Credit
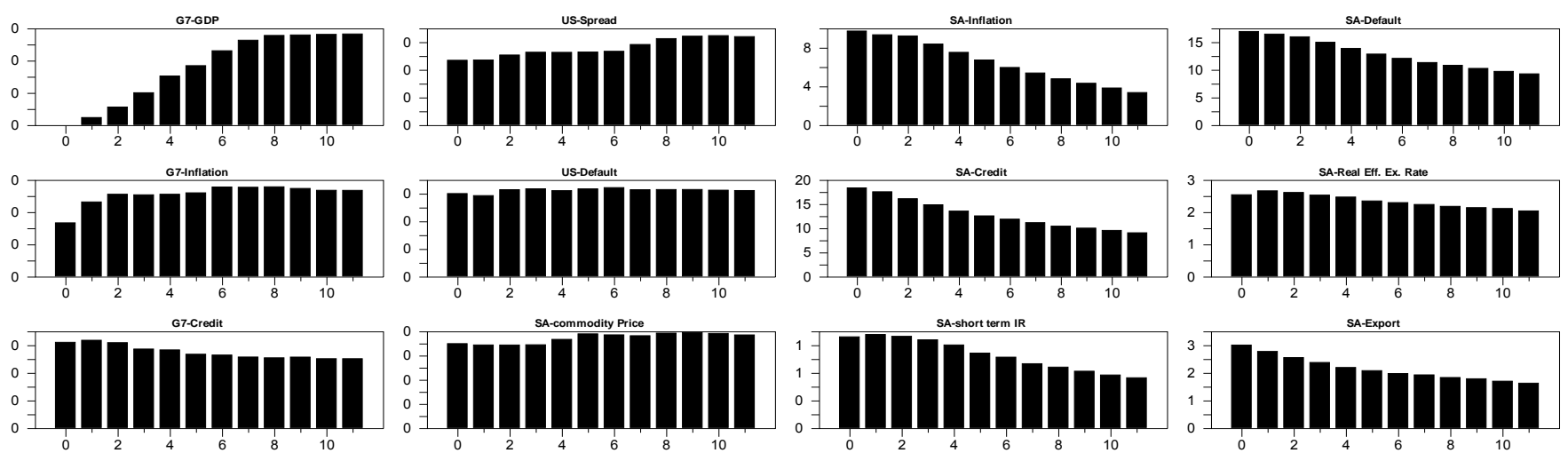

|||||||||||||
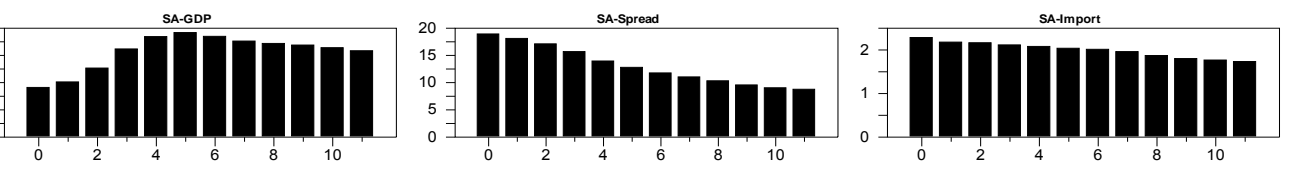
Figure 7: Variance explained by productivity shocks

\section{G7-Productivity}
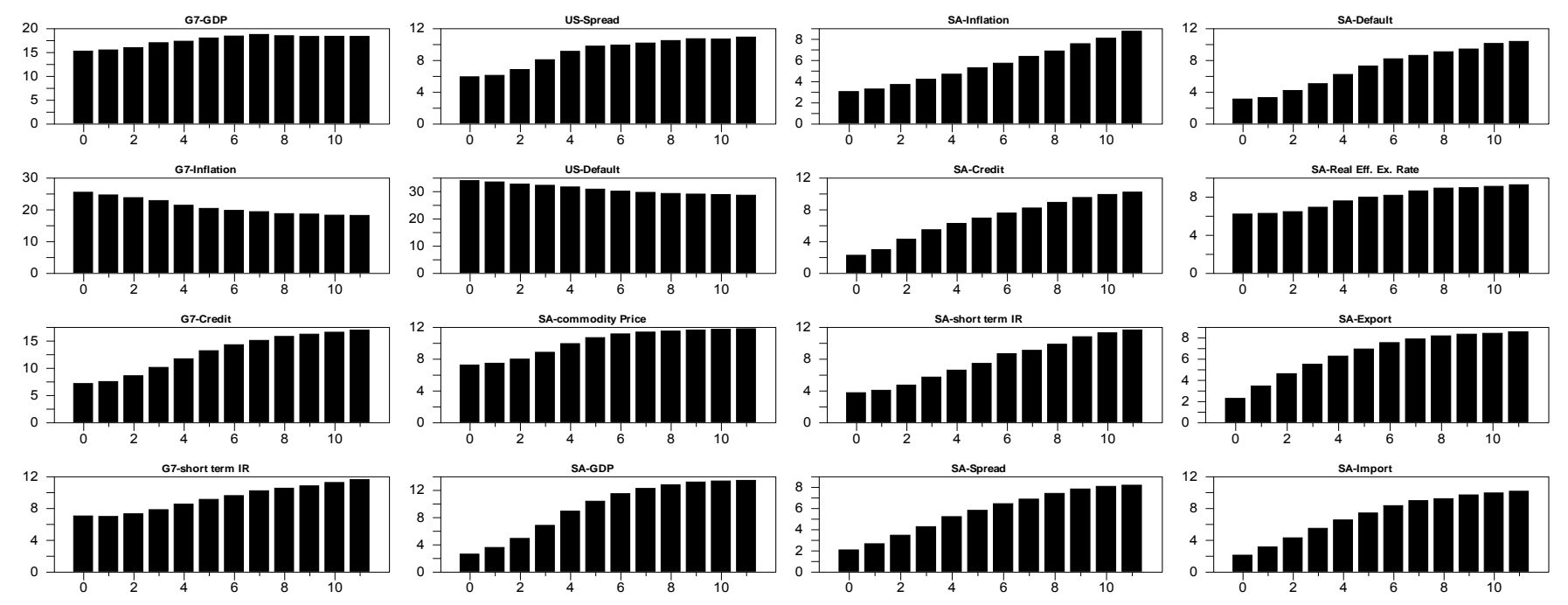

\section{SA-Productivity}
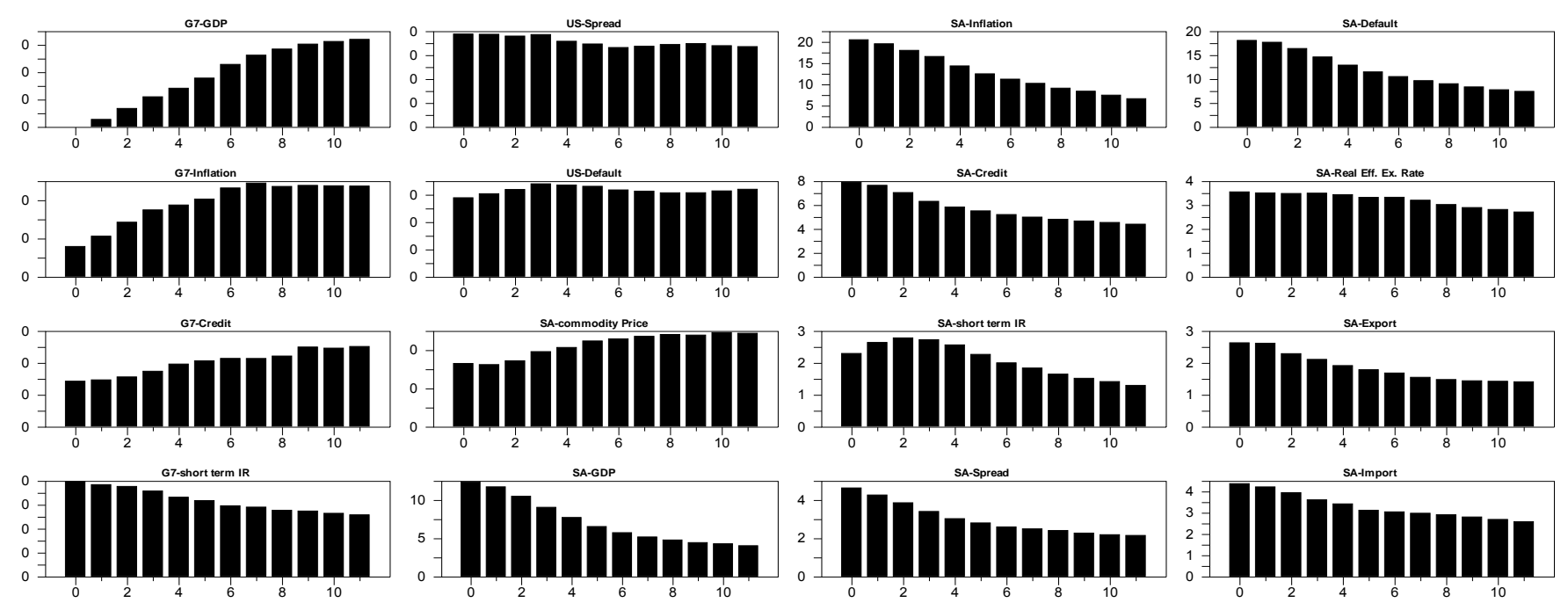
Figure 8: Variance explained by demand shocks

\section{G7-Demand}
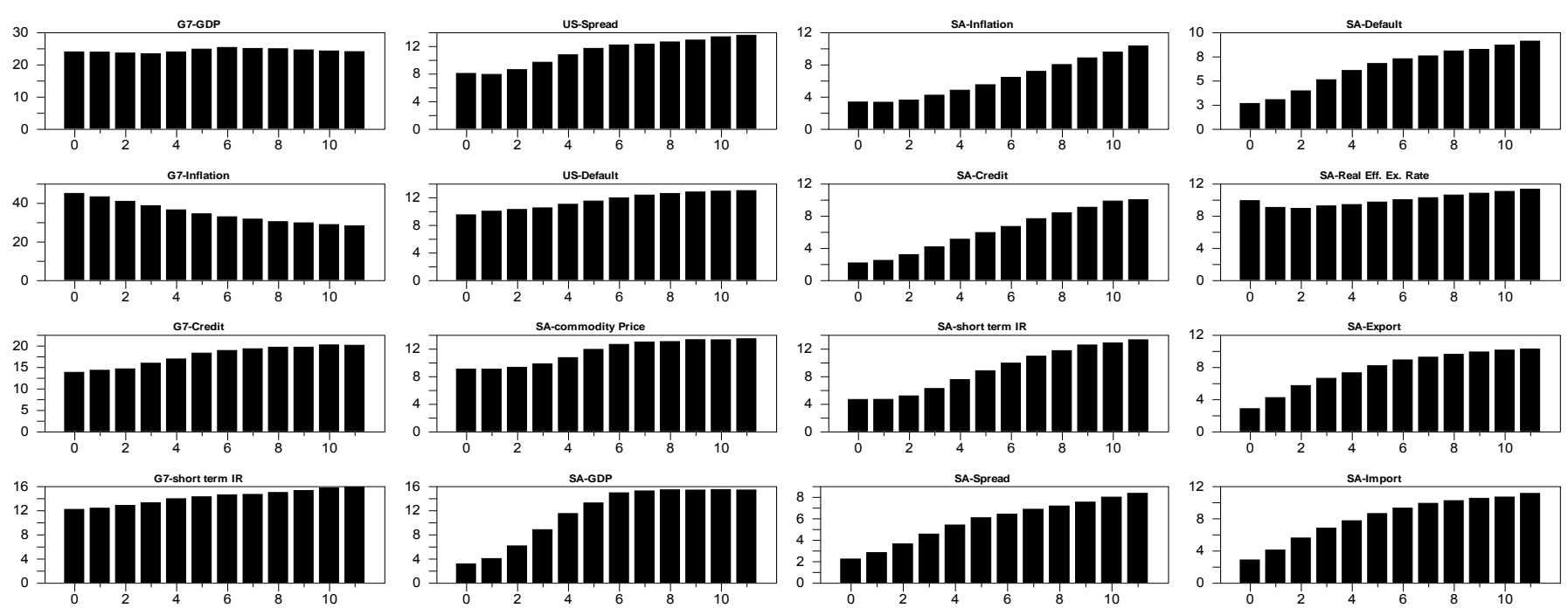

\section{SA-Demand}
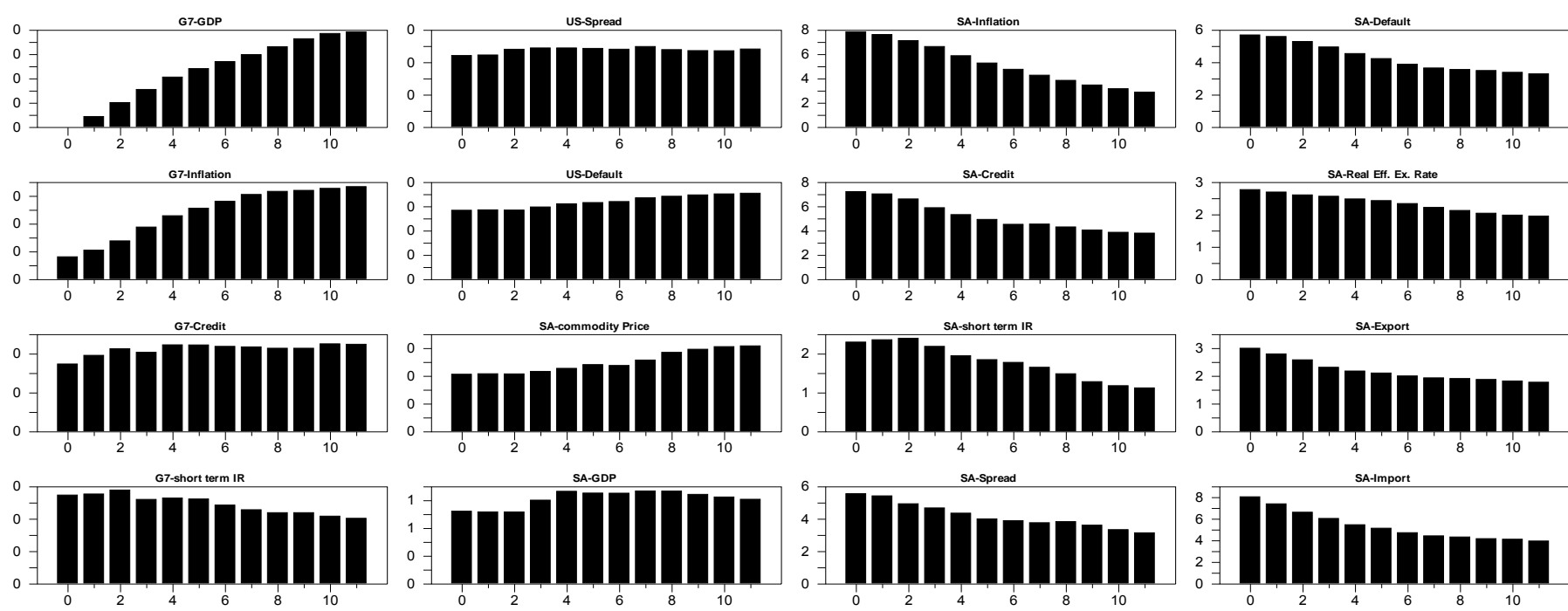
inflation in the short-run. In the short-run domestic productivity shocks also has the largest variance share of real activity in South Africa.

Third, the VD of other macroeconomic aggregates show a similar pattern. For instance, the variations of credit, default rates and credit spreads in South Africa are dominated by global shocks in the 3-year horizon. In the short run, however, domestic shocks are more important. Especially, domestic credit supply shocks explain the largest share of these indicators at the short-run horizon. Finally, the VD of the policy interest rate is dominated by global shocks.

\subsection{Counterfactual Analysis}

A final tool we use for studying the shocks is counterfactual analysis where, we examine the impact of the shocks at specific periods. In particular, we study the impacts of the three shocks in three periods where the South African economy experienced recessions: 1990 : $1-1992: 2 ; 1996: 3-1999: 1$ and $2007: 4-2010: 3$. Figures 9 to 14 report the results. The thin (blue) line represents the observed data whereas the tick (dark) line denotes the median dynamics of the series in the absence of a shock.

In line with the results presented above the data show that the global shocks have contributed the most to the decline of real activity in South Africa in 1990:1-1992:2 and 2007 : 4-2010 : 3. In 1996 : 3-1999 : 1, however, the domestic shocks have played the major role. This result is not surprising given the events behind the downturn of $1996: 3-1999: 1$ had to due more with issues related to South Africa and other EMEs as discussed above.

Our results also show that the trade and the credit linkages are the main transmission channels of global shocks to South Africa in $2007: 4-2010: 3$ whereas in $1990: 1-1992: 2$ the commodity price channel were the dominant channels. This result could be interpreted as the increase of globalization in recent years. However, one should also keep in mind that South Africa faced a number of economic and financial sanctions before 1994 as a result of Apartheid.

\section{Conclusion}

In this paper, we analyze the role of domestic and global credit shocks in explaining business cycles in Emerging Markets Economies (EMEs). For this purpose, we use a medium-scale Bayesian Vector Auto-Regressive (BVAR) model that captures the main dynamics of 16 macroeconomic indicators in G7-countries and in South Africa. Moreover, we employ a set 

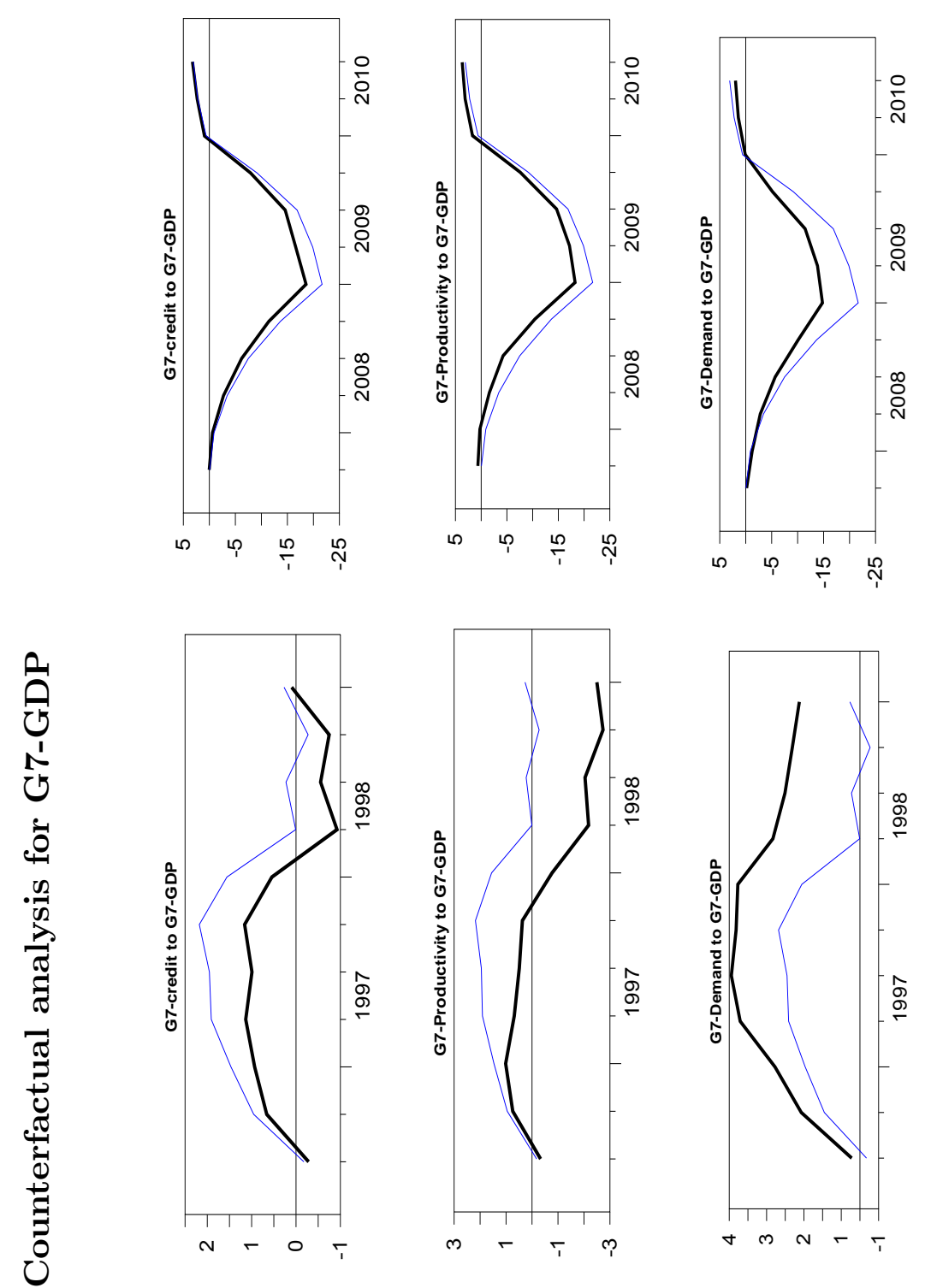

ö
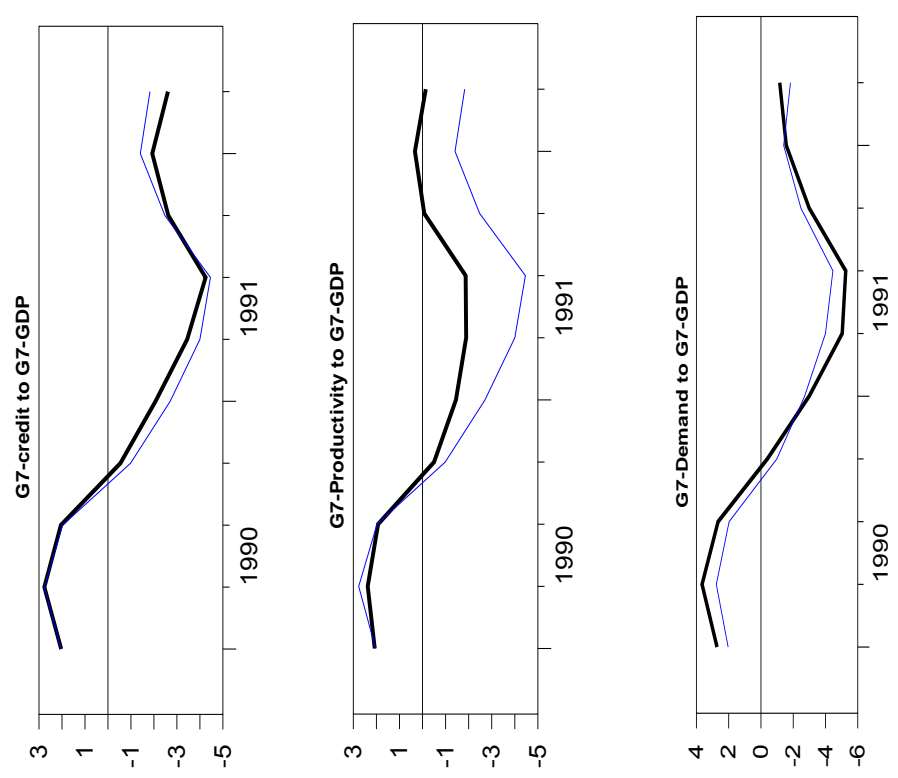

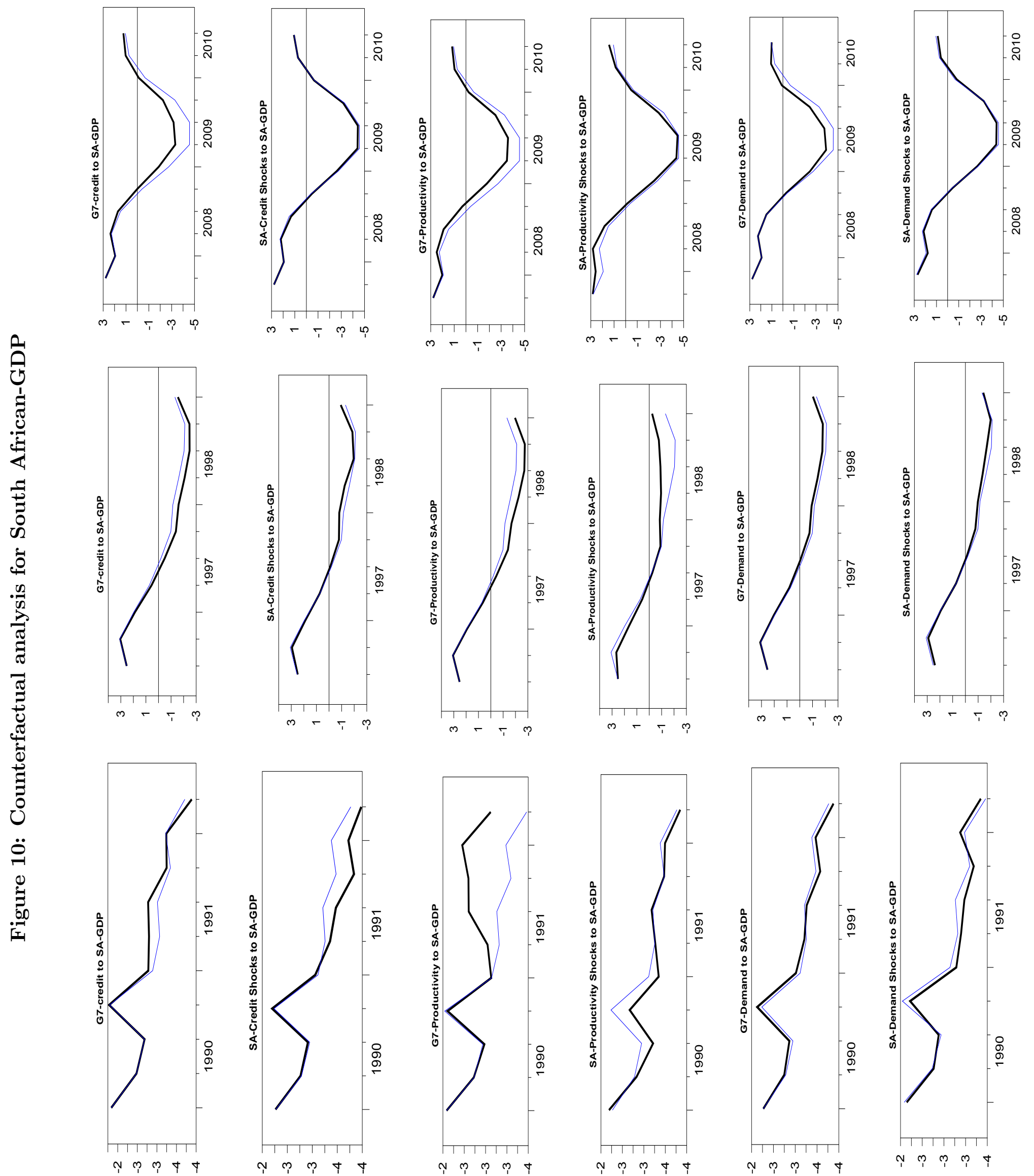


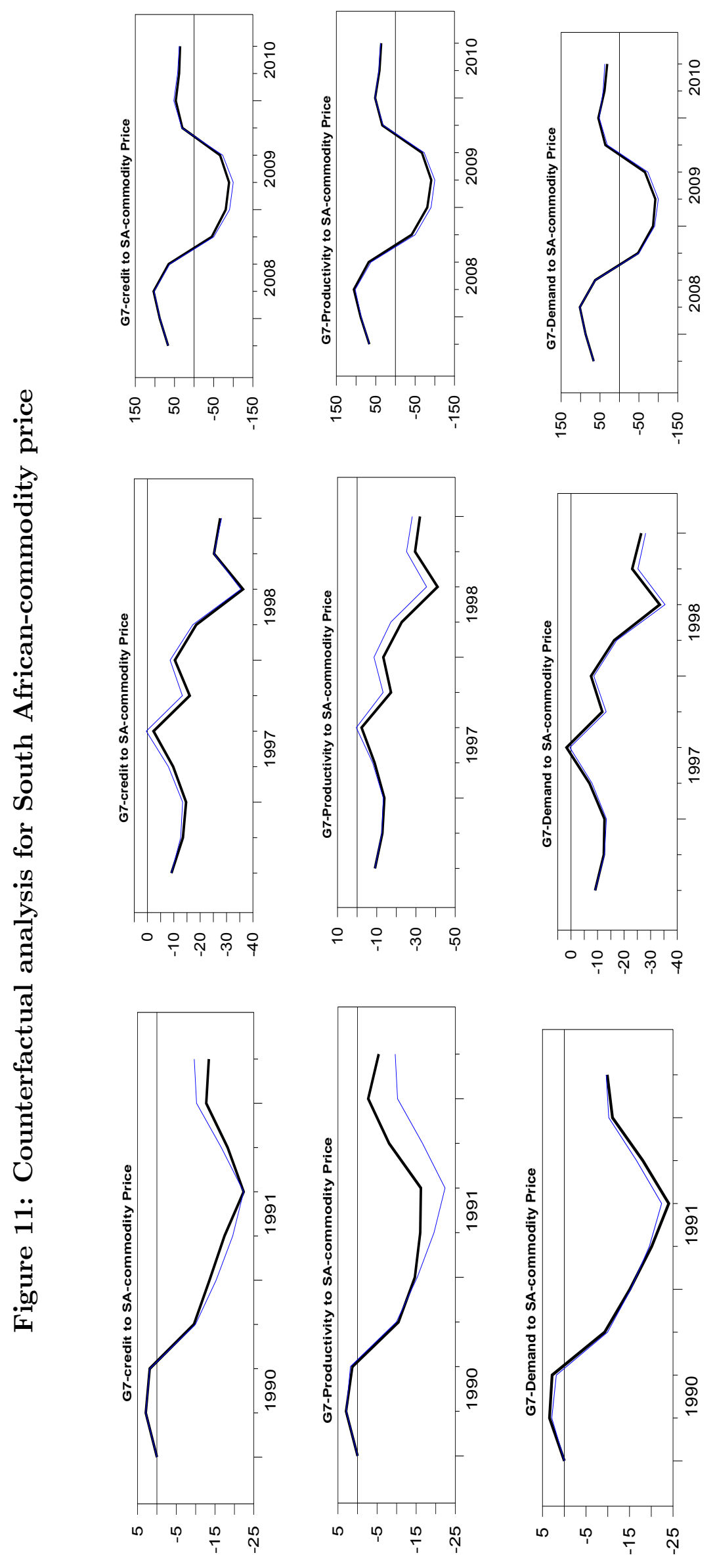




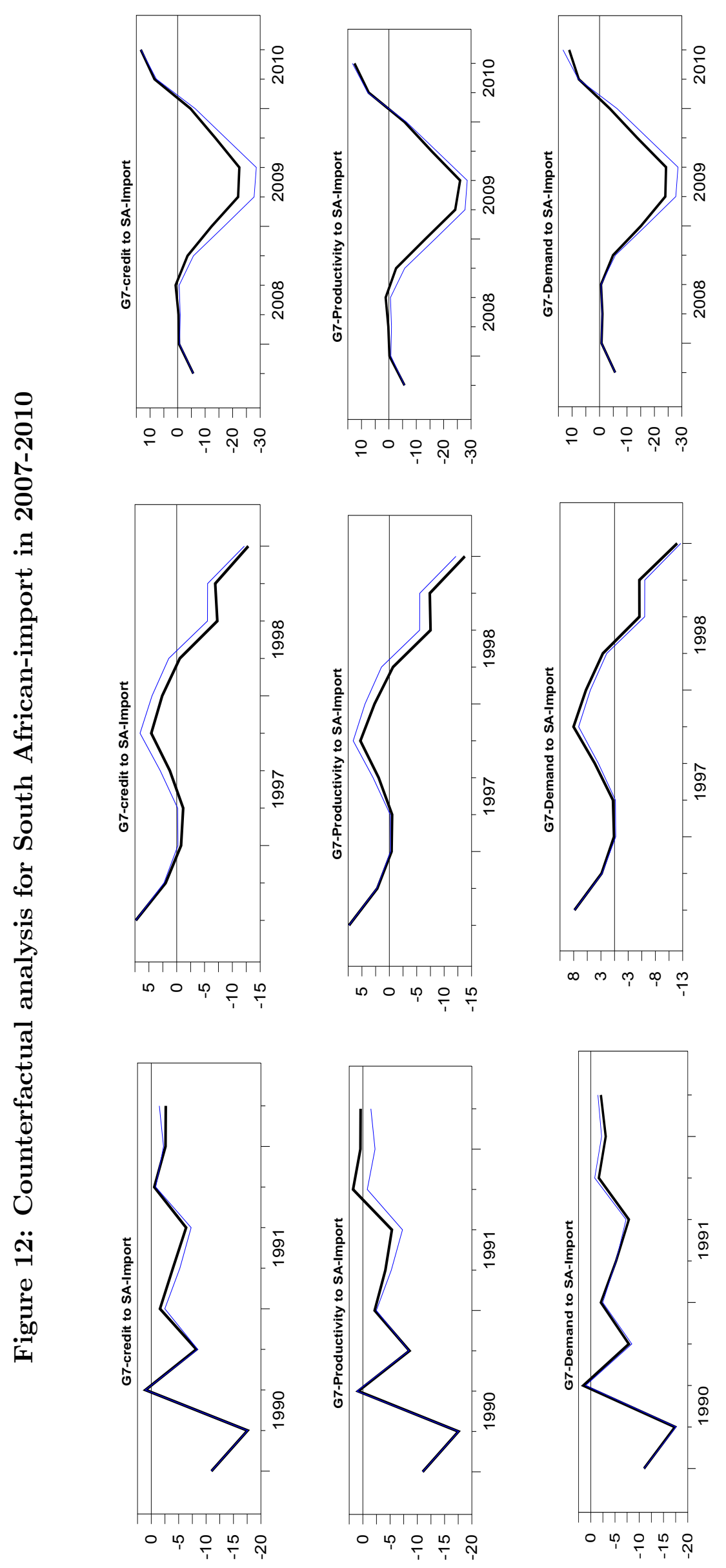




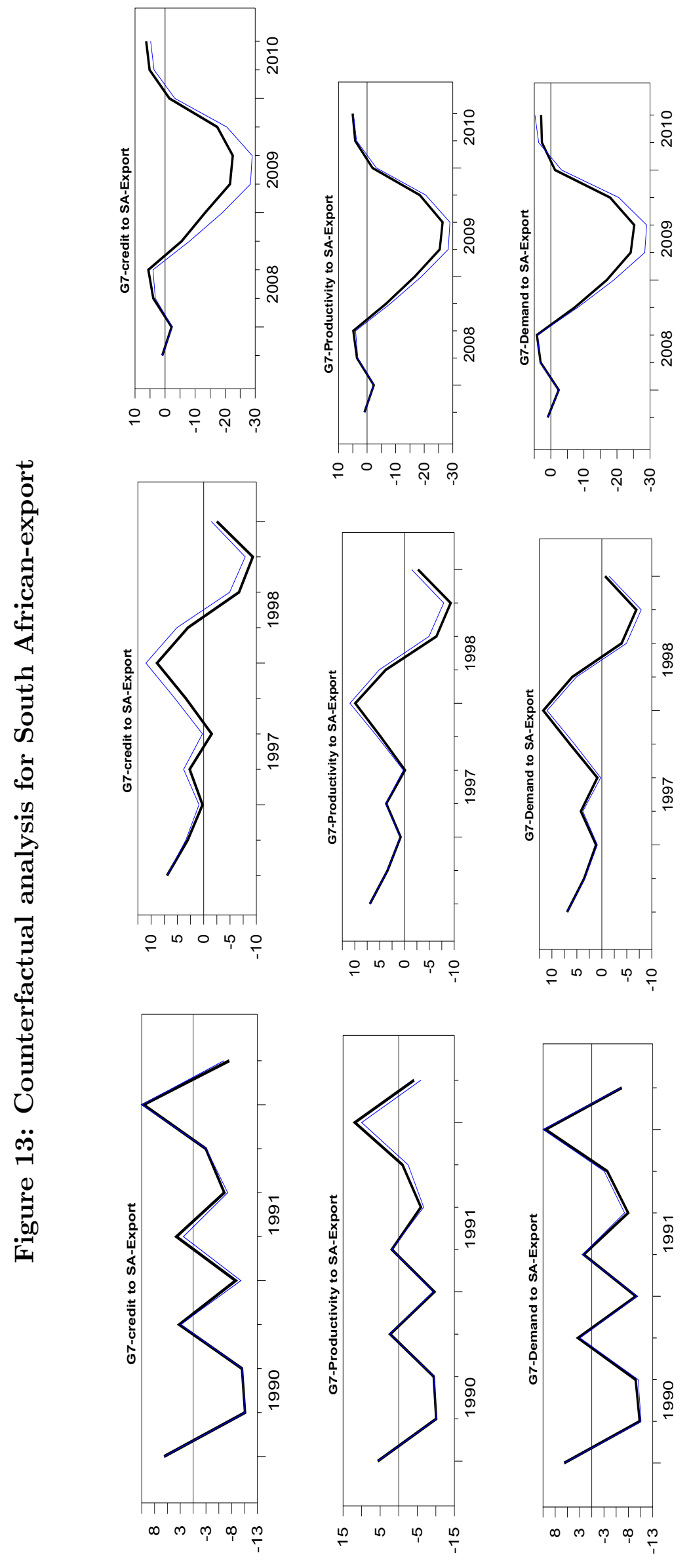



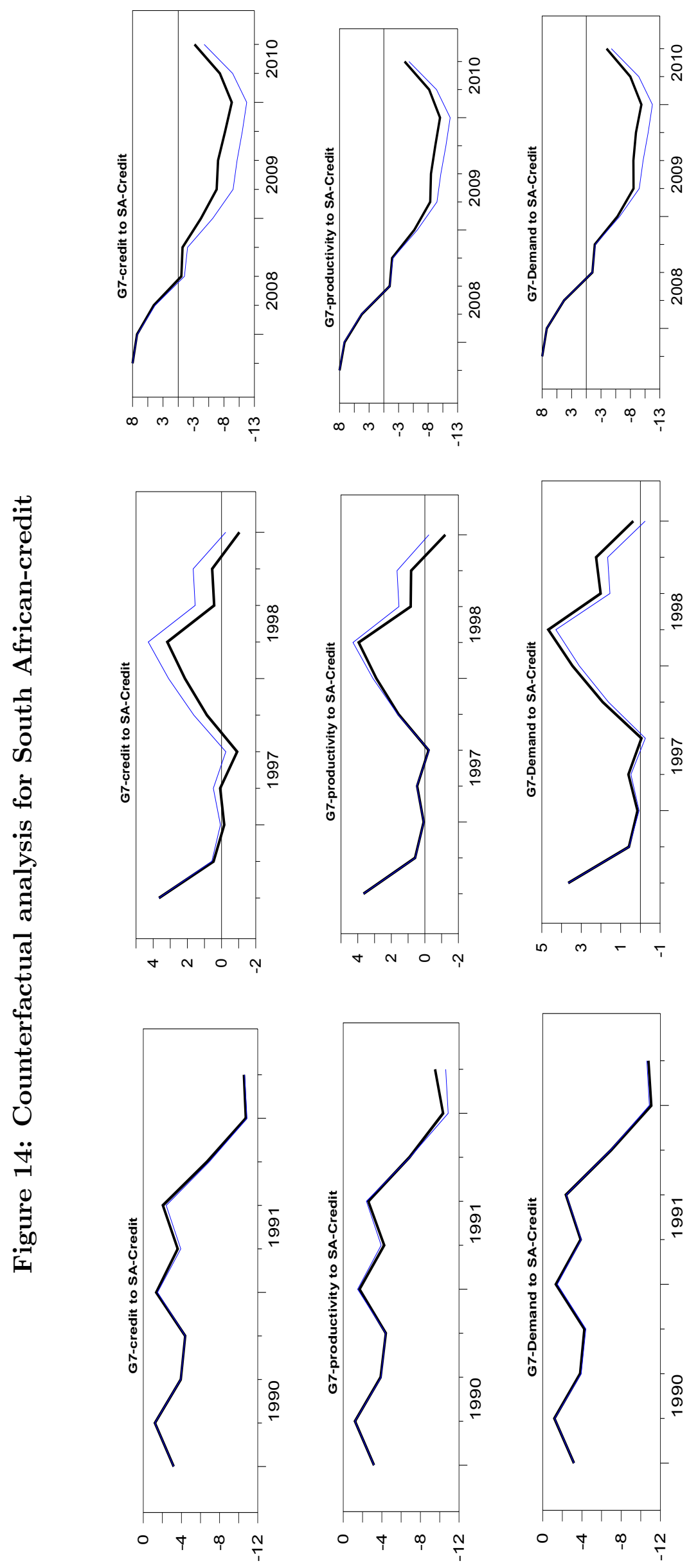
of zeros and sign restrictions. Quarterly data in 1985 : 1 - 2010 : 3 show that credit supply shocks impact significantly on macroeconomic fluctuations in both the G7-countries and South Africa. However, the fundamental shocks remain the main drivers of real activity.

\section{References}

Abildgren, K. (2012). Financial structures and the real effects of credit-supply shocks in denmark 1922Ü2011. European Review of Economic History 16(4), 490-510.

Akinboade, O. A. and D. Makina (2010). Econometric analysis of bank lending and business cycles in south africa. Applied Economics 42(29), 3803-3811.

Atta-Mensah, J. and A. Dib (2008). Bank lending, credit shocks, and the transmission of canadian monetary policy. International Review of Economics \& Finance 17(1), 159-176.

Bernanke, B. S. and C. S. Lown (1991). The credit crunch. Brookings Papers on Economic Activity 22(2), 205-248.

Broda, C. (2004, May). Terms of trade and exchange rate regimes in developing countries. Journal of International Economics 63(1), 31-58.

Busch, U., M. Scharnagl, and J. Scheithauer (2010). Loan supply in germany during the financial crisis. Discussion paper series 1: Economic studies, Deutsche Bundesbank, Research Centre.

Canova, F. and G. D. Nicolo (2002, September). Monetary disturbances matter for business fluctuations in the g-7. Journal of Monetary Economics 49(6), 1131-1159.

Cetorelli, N. and L. S. Goldberg (2010, May). Global banks and international shock transmission: Evidence from the crisis. Working Paper 15974, National Bureau of Economic Research.

Chia, W.-M. and J. D. Alba (2006, 09). Terms-of-trade shocks and exchange rate regimes in a small open economy. The Economic Record 82(s1), S41-S53.

Curdia, V. and M. Woodford (2010, 09). Credit spreads and monetary policy. Journal of Money, Credit and Banking 42(s1), 3-35. 
Deaton, A. and R. Miller (1996, October). International commodity prices, macroeconomic performance and politics in sub-saharan africa. Journal of African Economies 5(3), 99191.

Faust, J. (1998, December). The robustness of identified var conclusions about money. Carnegie-Rochester Conference Series on Public Policy 49(1), 207-244.

Gambetti, L. and A. Musso (2012, September). Loan supply shocks and the business cycle. Working Paper Series 1469, European Central Bank.

Gerali, A., S. Neri, L. Sessa, and F. M. Signoretti (2010, 09). Credit and banking in a dsge model of the euro area. Journal of Money, Credit and Banking 42(s1), 107-141.

Gilchrist, S., V. Yankov, and E. Zakrajsek (2009, May). Credit market shocks and economic fluctuations: Evidence from corporate bond and stock markets. Journal of Monetary Economics 56(4), 471-493.

Gregory, A. W., A. C. Head, and J. Raynauld (1997). Measuring world business cycles. International Economic Review 38(3), 677-701.

Halvorsen, J. I. and D. H. Jacobsen (2009, December). Are bank lending shocks important for economic fluctuations? Working Paper 2009/27, Norges Bank.

Helbling, T., R. Huidrom, M. A. Kose, and C. Otrok (2011, April). Do credit shocks matter? a global perspective. European Economic Review 55(3), 340-353.

Hoffmaister, A. W., J. E. Roldos, and P. Wickham (1998). Macroeconomic fluctuations in sub-saharan africa. IMF Staff Papers 45(1), 5.

Hoffmaister, A. W. and J. Roldós (1997). Are business cycles different in asia and latin america. IMF Working Paper 97/9.

Houssa, R. (2008a). Asymmetric shocks in the west african monetary union. Technical report, AERC.

Houssa, R. (2008b, February). Monetary union in west africa and asymmetric shocks: A dynamic structural factor model approach. Journal of Development Economics 85(1-2), 319-347.

Houssa, R., C. Otrok, and R. Puslenghea (2010). A model for monetary policy analysis for sub-saharan africa. Open Economies Review 21(1), 127-145. 
Hristov, N., O. Hülsewig, and T. Wollmershäuser (2012). Loan supply shocks during the financial crisis: Evidence for the euro area. Journal of International Money and Finance 31(3), 569-592.

Kose, A. M., C. Otrok, and C. Whiteman (2003). International business cycles: World, region, and country-specific factors. American Economic Review 93(4), 1216-1239.

Kose, M. A. (2002, March). Explaining business cycles in small open economies: 'how much do world prices matter?'. Journal of International Economics 56(2), 299-327.

Kose, M. A., E. S. Prasad, and M. E. Terrones (2003). How does globalization affect the synchronization of business cycles? American Economic Review 93(2), 57-62.

Kose, M. A. and R. Riezman (2001, June). Trade shocks and macroeconomic fluctuations in africa. Journal of Development Economics 65(1), 55-80.

Meeks, R. (2012). Do credit market shocks drive output fluctuations? evidence from corporate spreads and defaults. Journal of Economic Dynamics and Control 36(4), 568-584.

Mendoza, E. G. (1995). The terms of trade, the real exchange rate, and economic fluctuations. International Economic Review 36(1), 101-37.

Mountford, A. and H. Uhlig (2009). What are the effects of fiscal policy shocks? Journal of Applied Econometrics 24(6), 960-992.

Schnabl, P. (Forthcoming). The international transmission of bank liquidity shocks: Evidence from an emerging market. Journal of Finance.

South African Reserve Bank (1986-1995). Quarterly economic review, various publications in 1986-1995.

South African Reserve Bank (1996-2005). Quarterly economic review, various publications in 1996-2005.

Tamasi, B. and B. Vilagi (2011). Identification of credit supply shocks in a bayesian svar model of the hungarian economy. MNB Working Papers 2011/7, Magyar Nemzeti Bank (the central bank of Hungary).

Torsten, S. and L. Zwick (2012, August). In search for a credit crunch in germany. Ruhr Economic Papers 0361, Rheinisch-Westfälisches Institut für Wirtschaftsforschung, RuhrUniversität Bochum, Universität Dortmund, Universität Duisburg-Essen. 
Trautwein, H.-M. (2000, April). The credit view, old and new. Journal of Economic Surveys $14(2), 155-89$.

Uhlig, H. (2005, March). What are the effects of monetary policy on output? results from an agnostic identification procedure. Journal of Monetary Economics 52(2), 381-419.

Van der Walt, B. E. and W. S. Pretorius (1995). Business cycles in south africa during the period 1986 to 1993. SARB Quarterly Bulletin.

Venter, J. and W. Pretorius (2001). A note on the business cycle in south africa during the period 1997Ü1999. SARB Quarterly Bulletin, 63-69.

Venter, J. C. (2009). Business cycles in south africa during the period 1999 to 2007. Quarterly Bulletin Pretoria: South African Reserve Bank 253, 61-69. 